\title{
Saponin accumulation in cell suspension culture of Ehretia asperula Zollinger et Moritzi
}

\author{
Le Thi Tam Hong, Tran Van Minh
}

\begin{abstract}
This study was intended to investigate the saponin accumulation in the cell suspension culture of Ehretia asperula Zolliger et Moritzi. Soft, friable callus was initiated and grew well in MS medium supplemented with coconut water $10 \%$, sucrose $30 \mathrm{~g} / \mathrm{L}$, BA (6-benzylaminopurine) $0.1 \mathrm{mg} / \mathrm{L}$ and $2,4-\mathrm{D}$ (2,4-Dichlorophenoxyacetic acid) $2-2.5 \mathrm{mg} / \mathrm{L}$, with callus induction rate $93.52 \%$ and $92.59 \%$; callus diameter 18.33 and $17.00 \mathrm{~mm}$; and growth index 3.44 and 3.38 , respectively, after 24 days of culture. The callus cultured in MS (Murashige \& Skoog) medium added with BA $0.1 \mathrm{mg} / \mathrm{L}$ and $2,4 \mathrm{D} 2.0 \mathrm{mg} / \mathrm{L}$ were chosen to initiate the cell culture. The cell culturing experiments studied the effect of the agitating speed, the initial cell to medium ratio, and the addition of elicitor (methyl jasmonate)/precursor (phenylalanine) on the cell proliferation and the saponin accumulation. The cell suspension proliferated best at $140 \mathrm{rpm}$ of agitation (growth index 7.81 ) and $40 \%$ of the initial cell to medium ratio (growth index 7.96 ). The highest saponin content $(71.1 \mu \mathrm{g} / \mathrm{g})$ was detected with the use of methyl jasmonate $(10 \mathrm{mg} / \mathrm{L})$ in the culture medium.
\end{abstract}

Keywords - Ehretia asperula Zolliger et Moritzi, callus, cell suspension, saponin, 2,4-D

\section{Introduction}

Cancer is the second leading cause of death worldwide. In fact, the number of global death cases from cancer is estimated to reach 9.6 million in 2018 (Bray et al., 2018). One of the most practical approaches to control this disease is cancer chemoprevention by phytochemicals. Since saponins can cause apoptosis in tumor cells, they have become valuable drugs for cancer treatment, even in clinical practice (Man et al., 2010).

Despite the rising demand for therapeutic molecules, the striking reduction of biodiversity, and the slow growth rate of plant species lead to the requirement of an alternative practice for the production of high-value plant-derived metabolites (Georgiev et al., 2009), replacing the traditional method of direct extraction from the plant. The plant cell culture has been an alternative approach with shorter culturing period and more stable biochemical content.

Ehretia asperula Zoll. et Mor., locally called “xa den”, which belongs to Boraginaceae family (Sung et al., 2009), has been used in traditional medicine in Vietnam in assisting the treatment of ulcers, tumors, and inflammation

\section{Tran Van Minh}

International University - Vietnam Natianal University - Ho Chi Minh City

Le Thi Tam Hong

International University - Vietnam Natianal University -Ho Chi Minh City
(Ly et al., 2006). This species in distributed in Vietnam, Myanmar, and Thailand (Thuy et al., 2006) and is valuable for its content of some phytochemicals, especially terpenoids with confirmed bioactivities in vitro (Kuo, 1997).

In this study, the optimum cell suspension culture condition of Ehretia asperula Zoll. et Mor. was investigated in order to obtain a high content of accumulated saponin.

\section{Materials and methods}

\section{A. Materials}

Plant materials: In vitro explants cultured from $30 \mathrm{~cm}$ plants of Ehretia asperula Zolliger et Moritzi originated from Long Bien - Hanoi - Vietnam.

Culture medium: MS (Murashige \& Skoog, 1962), 1/2MS (half-strength MS), WPM (Woody Plant Medium), B5 (Gamborg B5) media. The culture media was supplemented with phytohormones including BA (6benzylaminopurine), NAA ( $\alpha$-naphthaleneacetic acid), 2,4D (2,4-Dichlorophenoxyacetic acid), methyl jasmonate, phenylalanine; coconut water $(10 \%)$, sucrose $(30 \mathrm{~g} / \mathrm{L})$, agar $(0.8 \%)$ and autoclaved at $121^{\circ} \mathrm{C}$ and $1 \mathrm{~atm}$ condition.

Culture condition: room temperature $24 \pm 2^{0} \mathrm{C}$, relative humidity $65 \pm 2 \%$, radiation intensity $22 \mu \mathrm{mol} / \mathrm{m}^{2} / \mathrm{s}$.

\section{B. Methods}

\section{1) Callus culture}

The calli were induced from in-vitro leaf pieces $(1.0 \times 1.0 \mathrm{~cm})$ cultured in in photoperiod 24hrs of darkness and were subcultured every three weeks. The medium was adjusted to $\mathrm{pH} 5.8$ (for callus induction) or 5.6 (for callus subculture) before being autoclaved. Ascorbic acid $(50 \mathrm{mg} / \mathrm{L})$ and citric acid $(25 \mathrm{mg} / \mathrm{L})$ were added to the subculture media to reduce callus browning (Martin, 2006).

\section{2) Cell suspension culture}

The callus with the optimum culture medium examined from previous experiments was used to initiate the cell suspension. $3 g$ of callus was transferred to the liquid medium ( $\mathrm{pH}$ 5.6), and maintained at agitation (120rpm). The cell suspension with cell density of $6 \times 10^{4}$ cells $/ \mathrm{ml}$ was used in experiments 5, 6 and 7. (Cragg \& Newman 2009 and Vargas \& Flota, 2006)

\section{3) Callus/Cell evaluation}

The responses of callus in various media were expressed as the callus induction rate (Huang, 2015), the callus diameter, the morphology characteristics, the final fresh weight of callus after 24 days of culture, and the growth index (Sahrarro et al., 2014). The cell suspension was evaluated in terms of the cell density $\left(10^{4}\right.$ cells $\left./ \mathrm{ml}\right)$, the growth index and the saponin content $(\mu \mathrm{g} / \mathrm{g})$.

4) Experimental design 
All experiments were completely randomize designed with three replications, and three culture vessels (4 explants/vessel) for each replication. Data were collected 24 days after being cultured and analyzed by ANOVA using SPSS 2.0 software with LSD test at $p \leq 0.05$.

Experiment 1. The effect of culture media on callus initiation: The leaf explants $(1.0 \times 1.0 \mathrm{~cm})$ were cultured in four different media, including MS, 1/2 MS, WPM and B5. All media were supplemented with BA $(0.1 \mathrm{mg} / \mathrm{L})$ and $2,4-$ D (2.0mg/L).

Experiment 2. The effect of coconut water on callus proliferation: The callus separated from the leaf explants cultured in the corresponding media were subcultured into MS media added with BA $(0.1 \mathrm{mg} / \mathrm{L}), 2,4-\mathrm{D}(2.0 \mathrm{mg} / \mathrm{L})$ and coconut water $(0 ; 5 ; 10 ; 15$ and $20 \%)$, with an initial fresh weight of $0.5 \mathrm{~g} / \mathrm{vessel}$.

Experiment 3. The effect of sucrose on callus proliferation: The callus separated from the leaf explants cultured in the corresponding media were subcultured into MS media added with BA $(0.1 \mathrm{mg} / \mathrm{L}), 2,4-\mathrm{D}(2.0 \mathrm{mg} / \mathrm{L})$ and sucrose $(0 ; 20 ; 30$; and $40 \mathrm{~g} / \mathrm{L})$, with an initial fresh weight of $0.5 \mathrm{~g} /$ vessel.

Experiment 4. The effect of phytohormones on callus initiation and proliferation: The leaf explants $(1.0 \times 1.0 \mathrm{~cm})$ were cultured on MS medium supplemented with BA $(0.1 \mathrm{mg} / \mathrm{L})$ and $2,4-\mathrm{D}$ or NAA at different concentrations $(0$; $1.0 ; 1.5 ; 2.0 ; 2.5$; and $3 \mathrm{mg} / \mathrm{L}$ ) to induce callus formation. In the first subculture, $0.5 \mathrm{~g}$ callus was transferred to the corresponding subcultured media.

Experiment 5. The effect of agitating speed on the formation of cell suspension: The suspension with a cell density of $6 \times 10^{4}$ cells $/ \mathrm{ml}$ was transferred to fresh medium with an initial cell to medium ratio of $30 \%(\mathrm{v} / \mathrm{v})$. The cell cultures were continuously agitated at different speeds $(100$; 120 and 140rpm) on a rotary shaker.

Experiment 6. The effect of the initial cell to medium ratio on cell suspension proliferation: The suspension with a cell density of $6 \times 10^{4}$ cells/ml was transferred to fresh medium with different initial cell to medium ratios (10; 20; $30 ; 40$ and 50\%) and maintained in agitation at 120rpm.

Experiment 7. The effect of methyl jasmonate and/or phenylalanine on saponin accumulation: The optimal culture condition from the two previous experiments were applied in this investigation. The culture media were supplemented with methyl jasmonate $(0 ; 5 ; 10 ; 20$; and $30 \mathrm{mg} / \mathrm{L})$ and/or phenylalanine at $16.5 \mathrm{mg} / \mathrm{L}$ (or $100 \mu \mathrm{M})$.

\section{Results and discussion}

\section{A. The effect of culture media on callus initiation}

As can be seen from Table 1, MS medium induced the largest callus $(18.00 \mathrm{~mm})$. Thus, the optimal macro-elements for inducing callus was MS medium. Similarly, Sharma et al. (2017) reported that the optimal medium for culturing calli from Crataeva tapia L. was MS medium.

\section{B. The effect of coconut water on callus proliferation}

The addition of coconut water enhanced the callus proliferation. The control sample only produced $1.62 \mathrm{~g}$ fresh weight, with growth index 2.24, whereas coconut water at 10 and $15 \%$ resulted in 2.24 and $2.18 \mathrm{~g}$ of fresh weight, with the growth index 3.48 and 3.36, respectively (Table 2), which were obviously higher than those of other treatments. This outcome was similar to that of Al-Khayri (2010), which cultured callus from Pheonix dactylifera L. species.

\section{The effect of sucrose on callus proliferation}

The sucrose supplementation at $30 \mathrm{~g} / \mathrm{L}$ resulted in a significant increase of the fresh weight, reaching 2.20g, which was 3.40 times higher than the initial (Table 3). Hence, the sucrose concentration appropriate for callus growth was $30 \mathrm{~g} / \mathrm{L}$, which was similar to the studies of Frisch \& Camper (1987) and Wang et al. (2012), in which, the calli from Camellia sinensis Wang et al. (2012) on Panax ginseng.

\section{The effect of phytohormones on callus initiation and proliferation}

The addition of BA $(0.1 \mathrm{mg} / \mathrm{L})$ and $2,4-\mathrm{D}$ or NAA stimulated the formation of callus (Table 4). With the addition of BA $(0.1 \mathrm{mg} / \mathrm{L})$ and NAA, the callus induction rate was $100 \%$. For $2,4-\mathrm{D}$, the concentration of 2.0 and 2.5 $\mathrm{mg} / \mathrm{L}$ resulted in no statistically significant differences, with callus induction rate over $90 \%$ and callus diameter 17.00 18.33mm. After 24 days, the callus browning began.

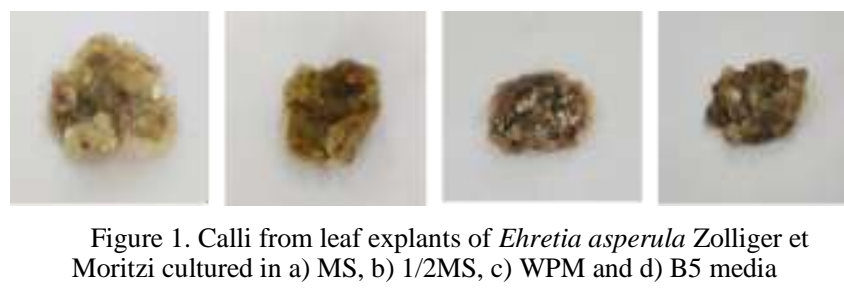

TABLE 1. THE EFFECT OF CULTURE MEDIA ON CALLUS INITIATION

\begin{tabular}{cccccl}
\hline Treatments & $\begin{array}{c}\text { Culture } \\
\text { media }\end{array}$ & $\begin{array}{c}\text { Callus induction rate } \\
(\mathbf{\%})\end{array}$ & Callus diameter $\mathbf{( m m )}$ & $\begin{array}{c}\text { Callus } \\
\text { formation }\end{array}$ & \multicolumn{1}{c}{ Morphology characteristics } \\
\hline $\mathbf{1}$ & MS & $91.67 \pm 2.78^{\mathrm{a}}$ & $18.00 \pm 1.00^{\mathrm{a}}$ & +++ & greenish, friable, soft \\
$\mathbf{2}$ & $1 / 2 \mathrm{MS}$ & $87.03 \pm 3.21^{\mathrm{a}}$ & $14.33 \pm 0.58^{\mathrm{b}}$ & ++ & greenish, friable, soft \\
$\mathbf{3}$ & WPM & $75.00 \pm 5.56^{\mathrm{b}}$ & $15.33 \pm 0.58^{\mathrm{b}}$ & + & greenish, a little soft \\
$\mathbf{4}$ & B5 & $85.18 \pm 1.61^{\mathrm{a}}$ & $15.33 \pm 1.53^{\mathrm{b}}$ & + & greenish, friable, a little harder \\
\hline
\end{tabular}

Note: The callus formation was indicated by + (present of callus), ++ (fair), and +++ (very good). Mean value in the same column with similar letter(s) are not significantly different at $\mathrm{p} \leq 0.05$ using LSD test. 
Proc. of the Eighth Intl. Conf. on Advances in Civil, Structural and Environmental Engineering - ACSEE 2019

Copyright (C) Institute of Research Engineers and Doctors. All rights reserved. ISBN: 978-1-63248-166-5 DOI : 10.15224/978-1-63248-166-5-04

TABLE 2. THE EFFECT OF COCONUT WATER ON CALLUS PROLIFERATION AFTER 24 DAYS OF CULTURE

\begin{tabular}{ccccc}
\hline Treatments & $\begin{array}{c}\text { Coconut } \\
\text { water } \\
\text { (\%) }\end{array}$ & $\begin{array}{c}\text { Callus } \\
\text { fresh } \\
\text { weight (g) }\end{array}$ & $\begin{array}{c}\text { Growth } \\
\text { index }\end{array}$ & $\begin{array}{c}\text { Callus } \\
\text { formation }\end{array}$ \\
\hline Control & 0 & $1.62 \pm 0.12^{\mathrm{a}}$ & 2.24 & ++ \\
$\mathbf{1}$ & 5 & $1.96 \pm 0.62^{\mathrm{b}}$ & 2.92 & ++ \\
$\mathbf{2}$ & $\mathbf{1 0}$ & $\mathbf{2 . 2 4} \pm \mathbf{0 . 2 2}^{\mathrm{c}}$ & $\mathbf{3 . 4 8}$ & +++ \\
$\mathbf{3}$ & $\mathbf{1 5}$ & $\mathbf{2 . 1 8} \pm \mathbf{0 . 0 8}^{\mathrm{c}}$ & $\mathbf{3 . 3 6}$ & +++ \\
$\mathbf{4}$ & 20 & $1.82 \pm 0.06^{\mathrm{b}}$ & 2.64 & ++ \\
\hline
\end{tabular}

Note: The callus formation was indicated by + (present of callus), ++ (fair), and +++ (very good).

The highest fresh weight and growth index were obtained by adding 2,4-D 2.0 and $2.5 \mathrm{mg} / \mathrm{L}$ to the media, with 2.22 and $2.19 \mathrm{~g}$ fresh weight respectively, rising by 3.44 and 3.38 times in comparing with the initial weight (Table 5). Thus, the optimal medium for callus growth was the MS medium supplemented with BA $(0.1 \mathrm{mg} /)$ and $2,4-\mathrm{D}(2.0$ or $2.5 \mathrm{mg} / \mathrm{L}$ ). The results were correlative with the researches of Sahoo et al. (1997) on Morus india L. and those of Wang (2012) on Panax ginseng.

\section{E. The effect of agitating speed on the formation of cell suspension}

The rotational speed obviously affected cell proliferation. The cell culture at 140rpm resulted in highest cell density $\left(16.33 \times 10^{4} \mathrm{cell} / \mathrm{ml}\right)$ and growth index (7.81) (Table 6). Thus, the speed of $140 \mathrm{rpm}$ is suitable for culturing cell
TABLE 3. THE EFFECT OF SUCROSE CONCENTRATIONS ON CALLUS PROLIFERATION AFTER 24 DAYS OF CULTURE

\begin{tabular}{ccccc}
\hline Treatments & $\begin{array}{c}\text { Sucrose } \\
\text { (g/L) }\end{array}$ & $\begin{array}{c}\text { Callus } \\
\text { fresh } \\
\text { weight (g) }\end{array}$ & $\begin{array}{c}\text { Growth } \\
\text { index }\end{array}$ & $\begin{array}{c}\text { Callus } \\
\text { formation }\end{array}$ \\
\hline Control & $Ð / \mathrm{C}$ & $0.62 \pm 0,34^{\mathrm{a}}$ & 0.24 & - \\
$\mathbf{1}$ & 20 & $1.84 \pm 0,16^{\mathrm{c}}$ & 2.68 & ++ \\
$\mathbf{2}$ & $\mathbf{3 0}$ & $\mathbf{2 . 2 0} \pm \mathbf{0 , 2 4 ^ { \mathrm { d } }}$ & $\mathbf{3 . 4 0}$ & +++ \\
$\mathbf{3}$ & 40 & $1.62 \pm 0,09^{\mathrm{b}}$ & 2.24 & ++ \\
\hline
\end{tabular}

Note: The callus formation was indicated by + (present of callus), ++ (fair), and +++ (very good)

suspension of Ehretia asperula Zolliger et Moritzi. This outcome was quite different from that of Singh \& Chaturvedi (2012) on Spilanthes acmella Murr. However, the agitating speed of $140 \mathrm{rpm}$ used to be applied successfully in culturing cell suspension of Catharanthus roseus (Tanaka et al., 1988).

\section{F. The effect of the initial cell to medium ratio on cell suspension proliferation}

After the time of culture, the cell density was the highest $\left(21.89 \times 10^{4}\right.$ cells $\left./ \mathrm{ml}\right)$, increased by 7.96 times with $40 \%$ of initial rate (Table 7). Hence, the appropriate cell to medium ratio for cell culture of Ehretia asperula Zolliger et Moritzi was $40 \%$, which was applied in the further experiment.

\begin{tabular}{|c|c|c|c|c|c|c|}
\hline \multirow{2}{*}{$\begin{array}{c}\text { Treatments } \\
\text { Control }\end{array}$} & \multicolumn{2}{|c|}{$\begin{array}{c}\text { Phytohormones } \\
\text { (mg/L) }\end{array}$} & \multirow{2}{*}{$\begin{array}{c}\begin{array}{c}\text { Callus induction rate } \\
(\%)\end{array} \\
-\end{array}$} & \multirow{2}{*}{$\begin{array}{c}\begin{array}{c}\text { Callus diameter } \\
\text { (mm) }\end{array} \\
-\end{array}$} & \multirow{2}{*}{$\begin{array}{c}\begin{array}{c}\text { Callus } \\
\text { formation }\end{array} \\
-\end{array}$} & \multirow{2}{*}{$\begin{array}{l}\text { Morphology characteristics } \\
\text { No callus formation }\end{array}$} \\
\hline & 0.0 & & & & & \\
\hline & $2,4 \mathrm{D}$ & $\mathrm{BA}$ & & & & \\
\hline 1 & 1.0 & 0.1 & $89.82 \pm 1.61^{b}$ & $16.33 \pm 1.53^{\mathrm{ab}}$ & ++ & Greenish, soft, friable \\
\hline 2 & 1.5 & 0.1 & $77.78 \pm 2.78^{\mathrm{a}}$ & $14.33 \pm 1.15^{\mathrm{a}}$ & ++ & Greenish, soft, friable \\
\hline 3 & 2.0 & 0.1 & $93.52 \pm 4.24^{\mathrm{b}}$ & $18.33 \pm 0.58^{\mathrm{b}}$ & +++ & Greenish, soft, friable \\
\hline \multirow[t]{2}{*}{5} & 3.0 & 0.1 & - & - & - & No callus formation \\
\hline & NAA & & & & & \\
\hline 6 & 1.0 & 0.1 & $100.00 \pm 0.00^{c}$ & $16.33 \pm 1.53^{\mathrm{ab}}$ & +++ & Yellow, hard, compact \\
\hline 7 & 1.5 & 0.1 & $100.00 \pm 0.00^{c}$ & $18.00 \pm 1.73^{\mathrm{b}}$ & +++ & Yellowish, hard, compact \\
\hline 8 & 2.0 & 0.1 & $100.00 \pm 0.00^{c}$ & $18.33 \pm 1.53^{\mathrm{b}}$ & +++ & Yellowish, hard, compact \\
\hline 9 & 2.5 & 0.1 & $100.00 \pm 0.00^{c}$ & $17.33 \pm 1.00^{\mathrm{b}}$ & +++ & Yellowish, hard, compact \\
\hline
\end{tabular}

Note: The callus formation was indicated by + (present of callus), ++ (fair), and +++ (very good) TABLE 6. THE EFFECT OF AGITATING SPEED ON THE FORMATION OF CELL SUSPENSION AFTER 24 DAYS OF CULTURE

\begin{tabular}{ccccc}
\hline $\begin{array}{c}\text { Treat- } \\
\text { ments }\end{array}$ & $\begin{array}{c}\text { Agitating } \\
\text { speed (rpm) }\end{array}$ & $\begin{array}{c}\text { Cell density } \\
\left(\mathrm{x} 10^{4} \text { cells/ml) }\right.\end{array}$ & $\begin{array}{c}\text { Growth } \\
\text { index }\end{array}$ & $\begin{array}{c}\text { Cell } \\
\text { suspension } \\
\text { formation }\end{array}$ \\
\hline 1 & 100 & $7.67 \pm 0.34^{\mathrm{a}}$ & 3.14 & ++ \\
2 & 120 & $11.89 \pm 0.19^{\mathrm{b}}$ & 5.42 & +++ \\
3 & 140 & $16.33 \pm 0.67^{\mathrm{c}}$ & 7.81 & +++ \\
\hline
\end{tabular}

Note: The cell suspension formation was indicated by + (present), ++ (fair), and +++ (very good).
TABLE 8. THE EFFECT OF THE INITIAL CELL TO MEDIUM RATIO ON THE CELL SUSPENSION PROLIFERATION AFTER 24 DAYS OF CULTURE

\begin{tabular}{ccccc}
\hline $\begin{array}{c}\text { Treat- } \\
\text { ments }\end{array}$ & $\begin{array}{c}\text { Initial Cell } \\
\text { to medium } \\
\text { ratio (\%) }\end{array}$ & $\begin{array}{c}\text { Cell density } \\
\text { (x10 cells/ml) }\end{array}$ & $\begin{array}{c}\text { Growth } \\
\text { index }\end{array}$ & $\begin{array}{c}\text { Cell } \\
\text { suspension } \\
\text { formation }\end{array}$ \\
\hline 1 & 10 & $1.00 \pm 0.11^{\mathrm{a}}$ & 0.35 & + \\
2 & 20 & $3.89 \pm 0.19^{\mathrm{b}}$ & 2.29 & + \\
3 & 30 & $12.00 \pm 0.67^{\mathrm{c}}$ & 5.88 & +++ \\
4 & 40 & $21.89 \pm 0.84^{\mathrm{d}}$ & 7.96 & +++ \\
5 & 50 & $7.89 \pm 0.70^{\mathrm{e}}$ & 1.59 & + \\
\hline
\end{tabular}

Note: The cell suspension formation was indicated by + (present), ++ (fair), and +++ (very good). 
Proc. of the Eighth Intl. Conf. on Advances in Civil, Structural and Environmental Engineering - ACSEE 2019

Copyright (C) Institute of Research Engineers and Doctors. All rights reserved. ISBN: 978-1-63248-166-5 DOI : 10.15224/978-1-63248-166-5-04

TABLE 5. THE EFFECT OF PHYTOHORMONES ON CALLUS PROLIFERATION AFTER 24 DAYS OF CULTURE

\begin{tabular}{ccccc}
\hline $\begin{array}{c}\text { Treat- } \\
\text { ments }\end{array}$ & $\begin{array}{c}\text { Phytohormones } \\
(\mathbf{m g} / \mathbf{L})\end{array}$ & $\begin{array}{c}\text { Callus fresh } \\
\text { weight } \mathbf{( g )}\end{array}$ & $\begin{array}{c}\text { Growth } \\
\text { index }\end{array}$ \\
\hline Control & 0.0 & & - & - \\
& $2,4 \mathrm{D}$ & BA & & \\
$\mathbf{1}$ & 1.0 & 0.1 & $1.10 \pm 0.09^{\mathrm{a}}$ & 1.20 \\
$\mathbf{2}$ & 1.5 & 0.1 & $2.00 \pm 0.04^{\mathrm{c}}$ & 3.01 \\
$\mathbf{3}$ & 2.0 & 0.1 & $2.22 \pm 0.14^{\mathrm{d}}$ & 3.44 \\
$\mathbf{4}$ & 2.5 & 0.1 & $2.19 \pm 0.02^{\mathrm{d}}$ & 3.38 \\
$\mathbf{5}$ & 3.0 & 0.1 & - & - \\
& $\mathrm{NAA}$ & & & 1.71 \\
$\mathbf{6}$ & 1.0 & 0.1 & $1.36 \pm 0.06^{\mathrm{b}}$ & 1.64 \\
$\mathbf{7}$ & 1.5 & 0.1 & $1.32 \pm 0.01^{\mathrm{b}}$ & 1.50 \\
$\mathbf{8}$ & 2.0 & 0.1 & $1.25 \pm 0.05^{\mathrm{b}}$ & 1.55 \\
$\mathbf{9}$ & 2.5 & 0.1 & $1.27 \pm 0.06^{\mathrm{b}}$ & 1.53 \\
\hline $\mathbf{1 0}$ & 3.0 & 0.1 & $1.26 \pm 0.03^{\mathrm{b}}$ & \\
\hline
\end{tabular}

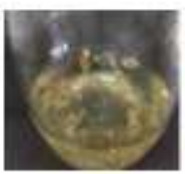

a

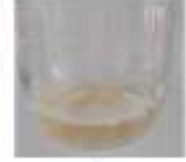

b

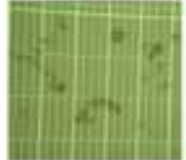

c

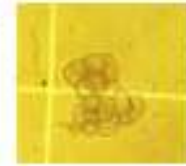

d
Figure 5. a) 3g of callus was transferred to liquid media to initiate cell suspension, b) Cell suspension cultured at $140 \mathrm{rpm}$ with the initial cell to medium ratio of $40 \%$ after 24 days, c) Cells observed under the microscope, d) Cell clumps

\section{G. The effect of methyl jasmonate and/or phenylalanine on saponin accumulation}

Saponin was not detected in the in-vitro explants and callus of Ehretia asperula Zolliger et Moritzi cultured on MS media supplemented with BA $(0.1 \mathrm{mg} / \mathrm{L})$ and $2,4-\mathrm{D}$ $(2.0 \mathrm{mg} / \mathrm{L})$ but was present in the cell suspension $(41.1$ $\mu \mathrm{g} / \mathrm{g})$. The control sample showed the highest cell density $\left(16.44 \times 10^{4}\right.$ cells $\left./ \mathrm{ml}\right)$ and growth index (5.73) (Table 8). The addition of methyl jasmonate and phenylalanine had a significant effect on cell proliferation and the total saponin accumulation of the suspension. With the supplementation of methyl jasmonate $(10 \mathrm{mg} / \mathrm{L})$, although cell proliferation decreased, the total saponin content increased significantly, reaching $71.1 \mu \mathrm{g} / \mathrm{g}$. Furthermore, by comparing the effects of methyl jasmonate alone and in combination with phenylalanine, it can be seen that methyl jasmonate predominated phenylalanine in stimulating saponin accumulation. Correlative results could be seen in the study of Wang et al. (2012) on Panax gingseng and Hayashi et al. (2003) on Glycyrrhiza glabra cell culture.

\section{Conclusion}

The optimal medium for callus and cell culture of Ehretia asperula Zolliger et Moritzi were MS medium supplemented with coconut water $(10 \%)$, sucrose $(30 \mathrm{~g} / \mathrm{L})$, BA $(0.1 \mathrm{mg} / \mathrm{L})$ and $2,4-\mathrm{D}(2.0 \mathrm{mg} / \mathrm{L})$. The appropriate rotational speed for cell proliferation was $140 \mathrm{rpm}$. The highest growth index was obtained with the initial cell to medium ratio of $40 \%$. Methyl jasmonate predominated phenylalanine in enhancing saponin accumulation in the cell suspension. The total saponin content increased significantly when methyl jasmonate $10 \mathrm{mg} / \mathrm{L}$ was added to the culture medium.

\section{Acknowledgment}

We express our appreciation to the International University - Vietnam National Unitversity - Ho Chi Minh City for providing the location and facilities for carrying this research.

\section{References}

[1] Bray F., Ferlay J., Soerjomataram I., Siegel R.L., Torre L.A., Jermal A. (2018). Global Cancer Statistics 2018: GLOBOCAN Estimates of Incidence and Mortality Worlwide for 36 Cancers in 185 Countries. CA: Cancer J. Clin. 68, 394-424.

[2] Man S, Gao W, Zhang Y, Huang L, Liu C (2010). Chemical study and medical application of saponins as anti-cancer agents. Fitoterapia 81 : 703-714.

[3] Cragg, G.M., Newman, D.J. (2009) Nature: a vital source of leads for anticancer drug development. Phytochem Rev, 8, 313-331

[4] Georgiev, M.I., Weber, J., Maciuk, A. (2009). Bioprocessing of plant cell cultures for mass production of targeted compounds. Appl Microbiol Biotechnol, 83, 809-823.

[5] Sung T.V., Cuong N.H., Ninh P.T., Thuy T.T. (2009). Isolation and determination of structure and biosynthesis of $\alpha$-amyrin derivatives from Ehretia dentata. Journal of Chemistry 47 (6): 691-697.

[6] Ly, T.N., Shimoyamada, M., Yamauchi, R., (2006). Isolation and characterization of rosmarinic acid oligomers in Celastrus hindsii Benth leaves and their antioxidative activity. J. Agric. Food Chem. 54, 3786-3793.

TABLE 7. THE EFFECT OF METHYL JASMONATE AND/OR PHENYLALANINE ON SAPONIN ACCUMULATION IN 24 DAYS OF CULTURE

\begin{tabular}{|c|c|c|c|c|c|}
\hline Treatments & $\begin{array}{c}\text { Methyl jasmonate } \\
\text { (mg/L) }\end{array}$ & $\begin{array}{l}\text { Phenylalanine } \\
\text { (mg/L) }\end{array}$ & $\begin{array}{l}\text { Cell density } \\
\left(\times 10^{4} \text { cells/ml) }\right.\end{array}$ & Growth index & $\begin{array}{l}\text { Total saponin } \\
\text { content }(\mu \mathrm{g} / \mathrm{g})\end{array}$ \\
\hline Control & 0 & 0 & $16.44 \pm 1.26^{\mathrm{e}}$ & 5.73 & 41.1 \\
\hline 1 & 5 & 0 & $12.11 \pm 0.70^{\mathrm{d}}$ & 3.96 & 58.2 \\
\hline 2 & 10 & 0 & $8.55 \pm 0.39^{c}$ & 2.50 & 71.1 \\
\hline 3 & 20 & 0 & $4.33 \pm 0.34^{\mathrm{a}}$ & 0.77 & 26.1 \\
\hline 4 & 30 & 0 & $5.78 \pm 0.51^{\mathrm{b}}$ & 1.36 & 36.4 \\
\hline 5 & 10 & 16.5 & $11.56 \pm 0.5^{\mathrm{d}}$ & 3.73 & 55.6 \\
\hline 6 & 0 & 16.5 & $5.56 \pm 0.51^{b}$ & 1.27 & 44.5 \\
\hline
\end{tabular}


[7] Thuy, T.T., Cuong N.H., Sung, T.V. (2007). Triterpenes from Celastrus hindsii Benth. Journal of Chemistry, 45 (3), 373-376.

[8] Kuo YH, Kuo LMY (1997) Antitumour and anti-aids triterpenes from Celastrus hindsii. Phytochemistry 44: 1275-1281.

[9] Martin G., Geetha S. P., Raja S. S., Raghu A. V., Balachandran I., Ravindran P. N. (2006). An efficient micropropagation system for Celastrus paniculatus Willd: a vulnerable medicinal plant. J For Res 11, 461-465.

[10] Vargas, V.M.L. and Flota, F.V. (2006). Plant Cell Culture Protocols Second Edition. Totowa, New Jersey. Humana Press Inc.

[11] Huang, B., Han, L., Li, S., Yan, C. (2015). Optimization of induction, subculture conditions, and growth kinetics of Angelica sinensis (Oliv.) Diels callus. Phcog Mag. 11 (43), 574-578.

[12] Sahraroo, A., Babalar, M., Mirjalili, M.H., Moghaddam M.R.F., and Ebrahimic, S.N. (2014). In-vitro Callus Induction and Rosmarinic Acid Quantification in Callus Culture of Satureja khuzistanica Jamzad (Lamiaceae). Iran J Pharm Res. 13 (4), 14471456.

[13] Sharma P., Patil A., Patil D. (2018). Effect of culture media and growth hormones on callus induction in Crataeva tapia L. J Pharm Res Int 9 (2).

[14] Al-Khayri J.M. (2010). Somatic embryogenesis of Date Palm (Phenix dacylifera L.) Improved by coconut water. Biotechnology 9 (4): 477484.

[15] Frisch C.H., Camper N.D. (1987). Effect of synthetic auxins on callus induction from tea stem tissue. Plant cell tissue organ cult. 8, 207213.

About Author (s):

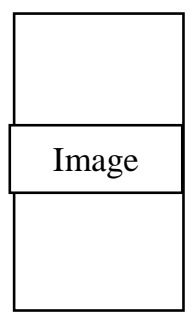

[Type a quote from the document or the summary of an interesting point. You can position the text box anywhere in the document. Use the Drawing Tools tab to change the formatting of the pull quote text box.]
[16] Wang J., Gao W., Zuo B., Zhang L., Huang L. (2012). Effect of methyl jasmonate on the ginsenoside content of Panax ginseng adventitious root cultures and on the genes involved in triterpene biosynthesis. Res Chem Intermed, 39, 1973-1980.

[17] Sahoo Y., Pattnaik S.K., Chand P.K. (1997). Plant regeneration from callus cultures of Morus indica L. derived from seedlings and mature plants. Sci. Hortic. 69: 85-98.

[18] Kumar S., Kanwar J.K. (2005). Plant Regeneration from Callus and Cell Suspension Cultures of Gerbera jamesonii cv. 'Diablo'. Europ.J.Hort.Sci. 70 (6): 265-270.

[19] Singh M., Chaturvedi R., (2012). Evaluation of nutrient uptake and physical parameeters on cell biomass growth and production of spilanthol in suspension cultures of Spilanthes acmella Murr. Bioprocess Biosyst Eng 35, 943-951.

[20] Tanaka H., Sembal H., Jitsufuchi T., Harada H. (1988). The effect of physical stress on plant cells in suspension cultures. Biotechnol Lett. 10 (7), 485-490.

[21] Krishna H, Sairam R.K., Singh S.K., Patel V.B., Sharma R.R., Grover M., Nain L., Sachdev A. (2008). Mango explant browning: Effect of ontogenic age, mycorrhization and pre-treatments. Sci. Hortic. 118, 132-138.

[22] Hayashi H., Huang P., Inoue K. (2003). Up-regulation of Soyasaponin Biosynthesis by Methyl Jasmonate in Cultured Cells of Glycyrrhiza glabra. Plant Cell Physiol 44 (4), 404-411. 